\title{
Sociological Dimensions of the FCP Method according to Christian Psychotherapy in Coping with Stress and Suffering
}

\author{
Naum llievski, PhD \\ Assistant Professorr, Faculty of Pedagogy, University "St. Clement of Ohrid", Bitola, Macedonia
}

Angelina llievska, MD,

Psychotherapist, Psychiatrist, Private Practice, Skopje, Macedonia

\begin{abstract}
The concept of the Five Control Points, FCP (systematized by the author), is a contemporary approach used in Christian Psychotherapy that arises from a specific personal and spiritual experience under the supervision of a spiritual father-psychotherapist. It enables productive and meaningful overcoming of stress, as well as of the process of suffering, on a personal and wider social level, developing an adaptive social response and effective functioning. This is a descriptive study of the applied FCP method. It consists of five control points based on the Christian spiritual practice (acceptance, thanksgiving, self-discernment, quiescence and prayer). In the classical approaches, dealing with stress occurs on a psychological level by activating the psychological defence mechanisms, the most common: suppression, denial, rationalization. With FCP there is a completely opposite reaction. The intrapsychic process and its dynamics shift in the domain of the spiritual self with phenomenon of positive transformation (metanoia). The FCP method stimulates a creative process of overcoming stress and suffering as a purposeful and useful integrated experience that enhances the capacity of existence by enabling further and continuous personal growth and development. The person maturing through this process is the unifying axis, the peacemaker and the pointer to the positive developmental direction in the family unit, the environment and the society as a wider context. The positive social impact of the concept can be observed by comparing the usual human behaviour and the behaviour of a person trained through the FCP method.
\end{abstract}

Keywords: FCP method, Christian psychotherapy, stress, suffering, defence mechanisms, metanoia, positive social impact

\section{Introduction}

Human existence is the greatest challenge for science, philosophy and the branches of sociology alike. Contemporary psychology imposes new paradigms in its explanation of man's functioning as a whole being. This entails a holistic approach in the interpretation, that is, beside the biological and psychological there is also a spiritual aspect to the whole being. Spirituality has undoubtedly been and will remain "the missing chain" in the scientific interpretation of man and his most profound inner forces.

The primary aim of this study is to offer a description of the FCP method-systematized for the first time by the authorand additionally to carry out its demystification by precise informing and understanding of the significance of spirituality from the viewpoint of Christian Psychotherapy and Christian Anthropology. The emphasis is on the spiritual dimension as a reality to human health and existence in general and as a basis for an overall social wellbeing.

This has already been undeniably and empirically shown in contemporary studies, like the one carried out by the National Institute of Health and Family Welfare (NIHFW), New Delhi, which made a survey in 2011 and pointed out the importance of the fourth dimension of health-the spiritual one beside the other three dimensions: physical, mental and social, defined and constituted by the WHO. Spiritual health has been defined as a state of being where an individual is able to deal with day-to-day life issues in a manner that leads to the realization of one's full potential, meaning and purpose of life and fulfilment from within. Such a state of being is attainable through self-evolution, self-actualisation and transcendence (Dhar, Chaturvedi and Nandan, 2011, pp. 275-82). 
Indisputable is the relation between the unfavourable life events and the states of stress, suffering and crisis in general. Stress has been invoked as a cause of major psychopathology, a precipitator or trigger of psychiatric illness, and a contributor to considerable mental anguish (Dimsdale, Keefe and Stein, 2000, p. 3775).

These states are most often related to a series of unwanted biological and psychological effects, above all, on an individual basis, such as psychosomatic diseases, anxious disorders and depression, which result in a professional, family and social dysfunction. They are also reflected wider and have a far-reaching effect within the family as a primary social structure and further, within the secondary social structures-the working place and the society as a wider social context. The spirituality and spiritual practices have been shown to have a positive impact on many of these lifestyle diseases (Dhar, Chaturvedi and Nandan, 2013, pp. 3-5).

This has also been proven empirically in a research study, which is a Master's thesis of the author-Psychological Aspects of the Process of Loss, Grieving and Overcoming the Loss of a Family Member (2015). The research was carried out on a sample of 108 examinees that were going through the process of grieving due to a loss of a family member. The examinees were categorized into three groups-believers, nominal believers and atheists, depending on their relation to religion and faith (obeying the church rules, principles, feasts, reading and listening to the Scriptures, Holy Eucharist, FCP method with a prayer).

The basic purpose was to point at the positive impact of spiritual life on one's psychological state, by examining the following parameters: anxiety, stress and depression. The psychological state of the first category of believers that have lost a family member is considerately on a higher level, with a lesser degree of anxiety, stress and depression than the other two groups. Next is the category of nominal believers, and the last is the category of atheists.

The received parameters indicate that the influence of the Church and the depth of spiritual life influence upon the psychological state of the examinees; this influence is statistically significant.

\section{Christian Psychotherapy}

The FCP method is the basis of Christian Psychotherapy and Christian practice in a wider sense, which is derived from the two-thousand-year experience of the holy teachers of the Church. It is based on the ascetical-hesychastic struggle (Митрополит Струмички Наум, 2011, pp. 19-20), which is the essence of Christian teaching.

According to the Christian Anthropology, man is both soul and body. The human soul consists of three powers: the rational one, which is the mind, and two irrational, the will and desire. Their center is man's spiritual heart. All of these powers need to function in reconciliation; otherwise, the man cannot be considered mentally healthy. The mind is the rational power by which the man personally and directly communicates with God (the Archetype of good), while the intellect is a secondary function or tool of the mind by which the man communicates with this world. The reconciliation of the primary function of the mind with its secondary function - the intellect, is of an essential importance.

In the Patristic ascetical literature, the cognizant Orthodox spiritual life or struggle in knowledge is developed at three levels of the spiritual growth: purification of the heart from passions, illumination of the mind and godlikeness. The level of spiritual growth is determined by the quality of prayer. These teachings have been lost in other Christian denominations.

According to the Christian Psychotherapy, without the reconciled activity of the primary and secondary function of the mind, which comprises the healing of the mind, the development of the human personality and the realization of one's personal identity are not possible (llievski, 2015, p. 168).

\section{FCP Method:}

Several authors have made an attempt to describe the phases or the stages which man goes through when facing stress and suffering. Mentioned very often is the method according to the psychologist Kübler-Ross (1969, p. 91), described for the first time in her book On Death and Dying. The original idea was a detailed description of the stages which a person goes through when facing the terminal phase in fatal illnesses and death (denial, anger, bargaining, depression and acceptance). Afterwards the same stages were used for describing the process which man goes through when grieving and mourning. Many disagree with this systematization and no one can definitely claim that this process is general, unavoidable and always brings a successful resolution in the end. 
These five stages undergone by an individual who leads unnatural way of life (soulfulness) are a total opposite to the five control points undergone by a Christian struggler who leads a natural way of life (spirituality), because from experience it is known that the former, closed in his created and fallen nature, is limited to undergo only the process of suppression, while the latter, because of a graceful and personal union with God, undergoes a process of transformation.

The FCP method is, in fact, the basis of the Orthodox struggle in general. It is ascetical by nature, which means that it is based, above all, on volition and action. It is a dynamic process of activating the deeper volition dynamisms, such as the rational will, according to St. Maximus the Confessor, as opposed to the primordial impulses, which are determined by the natural will (PG 91, 280a).

\section{Description of the Method:}

Each life challenge and trouble (temptation) is correctly overcome in the following way (Metropolitan Nahum of Strumica, 2015):

\section{Acceptance (accepting it as a gift of God);}

The key is in acceptance. He who accepts the temptation correctly has reached the end before setting out on his journey. It is the main turning point as an initial position. A sign that the temptation is accepted as a gift is when without changing itself at all-except our attitude towards it—-the temptation becomes to us a source of joy, consolation and grace.

2. Thanksgiving (giving thanks to God);

Gratitude as a positive emotional and spiritual state that enables the person an unhindered access to the greatest power of the spiritual self, as well as building a positive and constructive attitude towards various life occasions.

3. Self-discernment (self-examining with a humble self-conscience);

Keeping the locus of control to oneself, with an insight into one's own conduct and understanding his role into concrete life situations.

\section{Quiescence (stillness with a behavioural peacefulness);}

Not showing outwardly with some acting that one is being tempted.

5. Prayer (not as a battle against temptation, but as a continuous struggle of building union with God).

Prayerfully collecting its energy into God-in the heart, the mind comes to knowledge of God and realizes its own primary function. On the other hand, when scattering its energy through the senses in the world, the mind realizes its secondary function as intellect.

According to the previously said, the man struggles in a free and love manner in order his mind to act, above all, in its primary function-by prayerfully collecting its energy within the heart and prayerfully uniting him with God.

Prayer is also directly related to the coefficient of spiritual intelligence, a notion also defined by the author.

\section{Coefficient of Spiritual Intelligence}

The coefficient of spiritual intelligence is the ability-transformed by God's grace and acquired through a long-lasting struggle and experience derived from it, correctly and quickly to overcome every temptation that is standing before man's development (Митрополит Струмички Наум, 2015, pp. 62-63).

At a moment of temptation, the weakened mind usually uses its secondary function-overflowed by thoughts, it observes itself (becomes aware of the hurt and changed feelings), thinks about what has happened and how to respond adequately to the new situation-an action that contaminates its energy.

Instead of this, man can try immediately, through prayer, to redirect his energy so that his mind starts functioning in its primary function-an action that is transforming its energy.

We can also measure the time during which the mind, functioning in its primary function, succeeds to calm its overall mental sphere, and especially its conceptual sphere. 


\section{Dynamics of the Process:}

What does it look like the incorrect facing with unfavourable life situations that cause suffering and crisis?

1. Non-acceptance (manifesting a psychological resistance through the primitive mechanisms of defence-denial, projection), which leads to an intrapsychic conflict;

2. Acting out-showing aggressive impulses through emotions of anger and revolt;

3. Displacement-shifting the intrapsychic conflict to the outwards, which leads to losing the locus of control (Rotter, 1954);

4. Externalization-showing outward changes in behaviour;

5. If any prayer is used, it is understood as a battle against the problem.

Certainly, in order to learn how to act correctly at the moment of temptation it is necessary one to spend time in the struggle of self-enforcing-ascesis.

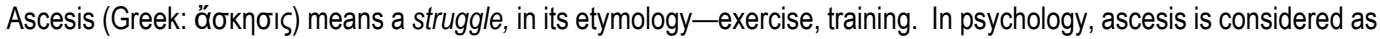
one of the mature defence mechanisms of personality, "The elimination of directly pleasurable affects attributable to an experience. The moral elements is implicit in setting values on specific pleasures. Asceticism is directed against all "base" pleasures perceived consciously, and gratification is derived from the renunciation" (adapted from Vaillant, 1977). It is a man's active struggle, whose initial position is acceptance as a crucial point that changes the entire intrapsychic process. Namely, more complex, mature psychological mechanisms arise, which have the function of dealing with newly arisen situations (stress, suffering), and not only the more primitive, defence mechanisms in the basis of which arises temporary dealing with the conflict on a suppression level.

It is a more profound process than the usual psychological model of one's acting while dealing with unfavourable factors, through which only the primitive mechanisms are managed and through which Ego keeps the dynamic equilibrium. With the first control point of acceptance, the dynamics, as well as the essence of the process, is shifted from the psychological level into the domain of spiritual existence-the spiritual self, whose core according to Orthodox Anthropology and Christian Psychotherapy is placed in the spiritual heart.

In the second case, there is only temporary restoring of an intrapsychic equilibrium, as opposed to the first. Applying the FCP, the moving energy Psihe, from the basic impetuses that are part of human nature, Survia and Passia, as named by the American psychologist Fanita English, penetrates into the level of Transcia (English, 2006).

Transcendence is the essential spiritual aspect, where the process of the deepest, crucial transformation metanoia takes place along with a profound repentance, which brings to a radical change of conscience or change of mind.

It is a crucial process that enables a complete processing of experience, their essential living and integration at all levels of one's existence. This, in fact, is a continuous process that is the core of the developing cycles, which leads to its utmost self-actualization as a whole being, that is, the spiritual being. More precisely, it is a complete existential realization where man lives the eternal determinedness in hic et nunc.

By the correct way of overcoming stress and suffering, one can realize the following - generating positive emotions and pleasant psychological and spiritual states, such as: love, mercy, forgiveness, thankfulness, peace, sharing, with an effect of repentance and mourning as a spiritual joy, not despair or euphoria. In addition, one realizes that the problem is never outside of him, but it is always inside him -in his attitude or relation to everything that happens, and that the only way to change the world around him is to change himself first.

\section{Spiritual Heart}

Central role in the existence of the Christian is his spiritual heart. It is the most powerful source of his being, living and overall existence. It is the eternal impetus (Oxford Advanced Learner's Dictionary, 2005). It is the momentum of a centripetal gathering of the energy $-P$ siche in its primordial center, the spiritual heart. It is a place of the most intimate meeting between God and man, a point of uniting between the created and the uncreated. The uncreated energy of God, that mystical elan vital (Bergson, 1911, pp. 87-97), is given to all by the act of Baptism in the Church. This energy is laid in the spiritual heart. The aim of Christian life and existence in general is-through cleansing of the heart from the passions-to activate and actualize the divine uncreated energy, which when manifested in the enough cleansed heart, 
shows us the place of the heart, and the mind receives the gift of the mind-and-heart prayer. It is this prayer that enables the personal union of man with God (Митрополит Струмички Наум, 2017). According to Paul Pearsall (1998, p. 4), "the heart thinks, cells remember, and that both of these processes are related to an as yet mysterious, extremely powerful, but very subtle energy with properties unlike any other known force."

\section{Sociological Dimension of the FCP Method:}

The practical application of the FCP method has a useful social impact on man, not only as an individual, but also on a wider scale, as a social dimension of his family and environment in general. According to Erickson's psycho-social development model, the producing of a "widening social radius" (Erickson, 1998, as cited in Sadock \& Sadock, 2005, p. 746) by reaching maturity through evolution not only of the emotional-social intelligence (Sadock, Sadock and Ruiz, 2015), but we would add, also by the coefficient of spiritual intelligence" (Митрополит Струмички Наум, 2015, pp. 59-67).

This is reflected in the development of a healthy mental and spiritual welfare, generating positive and useful spiritual values, such as: love, forgiving, reconciliation, readiness to share, quick and adequate overcoming of all life challenges, above all, of the unfavourable ones related to the states of stress and suffering.

The benefits are manifested not only in the subjective psychological welfare, but also such an individual is with a higher level of consciousness, responsibility and productivity within the social context. The continuous personal growth and development through this method enables increasing of one's capacities by means of a pro-social behaviour, that is, he overcomes the limits of his closed intrapersonal world and establishes quality interpersonal relations based on empathy and altruism. In such a way mature and complete personalities that are the unifying axis and a positive social model are created.

Contemporary society is facing a moral crisis and a crisis of values, and more than anytime there is a need of persons who are bearers of such inner coverage, who are the unifying axis, peacemakers and bearers of antinomical leadership.

Thus the domain and the outreach of the FCP method is widened, which - in its essence-is a dynamic and live process that enables a continuous growth and development of personality. This is the essential way of the development model from the perspective of Orthodox Anthropology, defined as a revelation in the opposite direction (Митрополит Струмички Haym, 2015, p. 111), where the highest achievement of man is his spiritual realization-the loving union with the divine in his open heart.

\section{References}

[1] Bergson, H. (1911). Creative Evolution. Mineola, NY: Dover Publications, pp. 87-97.

[2] Dhar, N., Chaturvedi, S., Nandan, D. (2011). Spiritual Health Scale 2011: Defining and Measuring 4th Dimension of Health. Indian J Community Med; 36:275-82.

[3] Dhar, N., Chaturvedi, S., Nandan, D. (2013). Spiritual Health, the Fourth Dimension: a Public Health Perspective. WHO South-East Asia J Public Health; 2:3-5.

[4] Dimsdale, J. E., Keefe, F. J., Stein, M. B. Stress and Psychiatry. In: Sadock, B. J., Sadock, V. A. (2000). Kaplan \& Sadock's Comprehensive Textbook of Psychiatry, Vol. 2 (7 $7^{\text {th }}$ ed.). Philadelphia, PA: Lippincott Williams \& Wilkins, p. 3775.

[5] English, F. (2006, April). Unconscious Constraints to Freedom and Responsibility. Transactional Analysis Journal, Vol. 36, No. 2.

[6] Erikson, E. H., Erikson, J. M. (1998). The Life Cycle Completed: Extended Version. New York, NY: W. W. Norton \& Company.

[7] Erikson, E. H. In: Sadock, B. J., Sadock, V. A. (2005). Kaplan \& Sadock's Comprehensive Textbook of Psychiatry, Vol. 1 (8 $8^{\text {th }}$ ed.). Philadelphia, PA: Lippincott Williams \& Wilkins, p. 746.

[8] Ilievski, N., Metropolitan of Strumica (2015). Basics of the Ascetical (Christian) Psychotherapy, Contributions. Sec. Med. Sci., XXXVI 1, MASA, pp. 165-173.

[9] Илиевски, Н. (2015). Психолошки аспекти на процесот на загуба, тагување и надминување на загубата на член во семејството. (Unpublished MD thesis). Меѓународен славјански универзитет „Гаврило Романович Державин“, Свети Николе, Македонија.

[10] Kübler-Ross, E. On Death and Dying [Kindle version]. Retrived from http://www.amazon.com 
[11] Metropolitan Nahum of Strumica. Only One Thing Is Needed [Kindle version]. Retrived from http://www.amazon.com

[12] Migne J.-P. (1994). Patrologia Graeca 91, 280a. Athens, Greece: Centre for Patristic Publications.

[13] Митрополит Струмички Наум (2011). Школа за исихазам: основна. Велјуса, Македонија: Манастир Воведение на Пресвета Богородица Елеуса.

[14] Митрополит Струмички Наум (2015). Премин од душевност во духовност. Велјуса, Македонија: Манастир Воведение на Пресвета Богородица Елеуса.

[15] Митрополит Струмички Наум (2017, August 19). Царството небесно прилега... на простување. Македонска Православна Црква - Охридска Архиепискоnија. Retrieved from http://mpc.org.mk/MPC/SE/vest.asp?id=6825.

[16] Oxford Advanced Learner's Dictionary (7th ed.). (2005). Oxford, England: Oxford University Press.

[17] Pearsall, P. (1998). The Heart's Code: Tapping the Wisdom and Power of Our Heart Energy (1st ed.) [Kindle version]. New York, NY: Broadway books.

[18] Rotter, J. B. (1954). Social Learning and Clinical Psychology. New York, NY: Prentice-Hall.

[19] Sadock, B. J., Sadock, V. A., Ruiz, P. (2015). Kaplan \& Sadock's Synopsis of Psychiatry: Behavioral Sciences/Clinical Psychiatry (11 ed.). Philadelphia, PA: Wolters Kluwer.

[20] Vaillant, G. E. (1998). Adaptation to Life. Boston, MA: Harvard University Press. 